Article

\title{
Directional Storm Surge in Enclosed Seas: The Red Sea, the Adriatic, and Venice
}

\section{Carl Drews}

Atmospheric Chemistry Observations \& Modeling, National Center for Atmospheric Research, P.O. Box 3000, Boulder, CO 80307, USA; E-Mail: drews@ucar.edu; Tel.: +1-303-497-1429;

Fax: +1-303-497-1400

Academic Editor: Rick Luettich

Received: 30 March 2015 / Accepted: 25 May 2015 / Published: 29 May 2015

\begin{abstract}
Storm surge is dependent on wind direction, with maximum surge heights occurring when strong winds blow onshore. It is less obvious what happens when a port city is situated at the end of a long narrow gulf, like Venice at the northwestern end of the Adriatic Sea. Does the narrow marine approach to the port city limit the dangerous wind direction to a span of only a few degrees? This modeling study shows that the response in surge height to wind direction is a sinusoidal curve for port cities at the end of a long inlet, as well as for cities exposed along a straight coastline. Surge height depends on the cosine of the angle between the wind direction and the major axis of the narrow gulf. There is no special protection from storm surge afforded by a narrow ocean-going approach to a port city.
\end{abstract}

Keywords: storm surge; Red Sea; Adriatic Sea; Venice; COAWST; ROMS; wind direction; wind setdown

\section{Introduction}

Wind-driven storm surge can cause great damage and loss of life in coastal regions. In August 2005, Hurricane Katrina struck the New Orleans, Louisiana, area and directly caused 1500 fatalities [1] (p. 11). In November 2013 Super Typhoon Haiyan made landfall near Tacloban City in the Philippines, generating a $6 \mathrm{~m}$ surge that drowned thousands of people [2]. Numerical models such as ADCIRC and Coupled Ocean Atmosphere Wave Sediment Transport (COAWST) seek to simulate the effects of 
tropical cyclones mathematically, and thereby provide timely forecasts for a threatened population. A real-time forecasting system can give advance warning to emergency managers in time to take action and perhaps order an evacuation. Static analyses of a port city's vulnerability can assist civil authorities in their long-term planning.

COAWST is a modeling framework that integrates the atmospheric model WRF (Weather Research and Forecasting) with the ocean model ROMS (Regional Ocean Modeling System), the wave model SWAN (Simulating WAves Nearshore), and the Community Sediment Transport Model [3]. COAWST provides a wetting and drying algorithm that simulates inundation and retreat of the ocean from the original shoreline [4]. Prior studies have demonstrated that COAWST can simulate storm surge accurately in its two-dimensional mode, which runs faster than 3-D [5,6]. For this study COAWST/ROMS was driven by idealized winds, without coupling to WRF or SWAN.

Drews and Galarneau (2015) presented a new technique for analyzing the surge potential of a coastal city when the wind is blowing from eight different compass points [6]. The present study expands this directional analysis and applies it to oblong enclosed bodies of water. The objective is to determine how a port city at the end of a long inlet is affected by storm surge. Is the port protected from winds outside a narrow range of directions? Or does a long narrow sea channel the surge toward the downwind end? The study results are applicable to several large coastal cities, such as New York City, NY, USA; Bangkok, Thailand; and St. Petersburg, Russia.

The Red Sea is a long narrow body of water between northeast Africa and the Arabian Peninsula. The northern end splits around the Sinai Peninsula into the shallow Gulf of Suez to the west, and the much deeper Gulf of Aqaba to the east (Figure 1). The Red Sea proper (south of Sinai) is also deep. The Suez Canal terminates at the port of Suez, providing an important marine connection between the Mediterranean Sea and the Indian Ocean. Deep-draft vessels should recognize the effects of wind on water levels in the Gulf of Suez. Table 1 lists the dimensions of bodies of water included in this study.

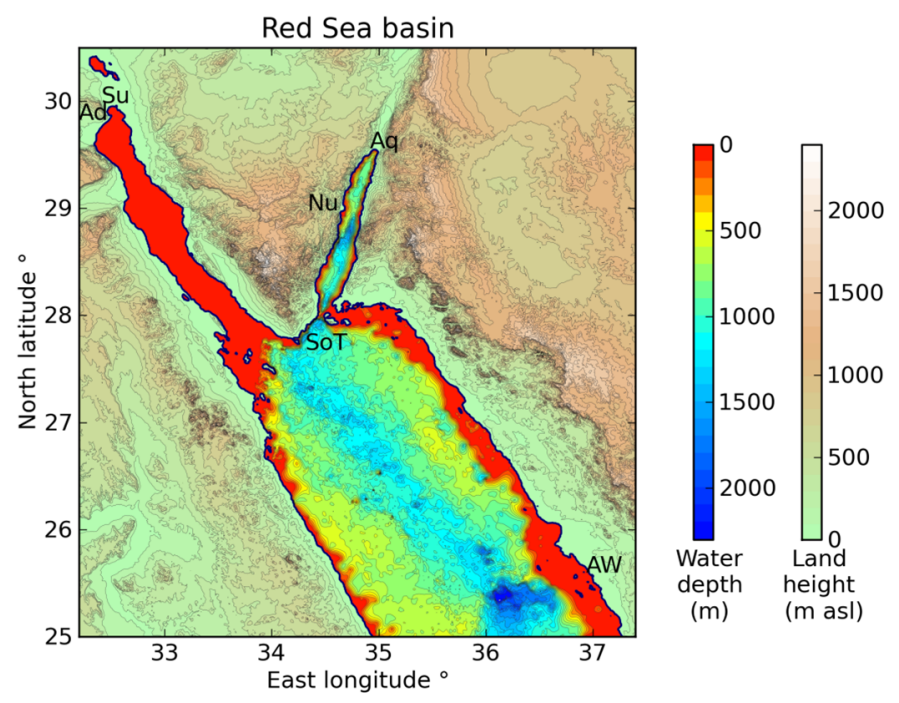

Figure 1. Red Sea domain. The northern section of the Red Sea splits into the shallow Gulf of Suez to the west (left); and the deeper Gulf of Aqaba to the east (right). The contour interval is $100 \mathrm{~m}$. Su = Suez; Ad = Adabiya; SoT = Straits of Tiran; Nu = Nuweiba; $\mathbf{A q}=$ Aqaba; $\mathbf{A W}=$ Al-Wajh. Sill depths are: Nuweiba $780 \mathrm{~m}$, Enterprise Passage $250 \mathrm{~m}$ through the Straits of Tiran. 
Table 1. Dimensions of seas and gulfs. The average depths are calculated by averaging all SRTM30 grid points below sea level. The Red Sea proper is south of the Sinai Peninsula and the Straits of Tiran. The modeled Red Sea domain extends south only to $25^{\circ}$ North latitude.

\begin{tabular}{cccc}
\hline Name & Length $(\mathbf{k m})$ & Width $(\mathbf{k m})$ & Average Depth (m) \\
\hline Gulf of Suez & 300 & 30 & 41 \\
Gulf of Aqaba & 180 & 18 & 546 \\
Red Sea proper & 1940 & 190 & 750 \\
Adriatic Sea & 790 & 130 & 218 \\
\hline
\end{tabular}

Storm surge height increases with the fetch distance of open water along which the wind blows. For example, at Aqaba/Eilat the fetch distance is fairly short $(\sim 10 \mathrm{~km})$ unless the wind direction is exactly aligned with the Gulf. The Gulf of Aqaba stretches $174 \mathrm{~km}$ from the Straits of Tiran to Aqaba. Figure 2 shows the fetch distance at Aqaba plotted according to compass direction. One might expect the surge height at Aqaba to display a similarly narrow spike when the wind blows directly out of Tiran.

Fetch Distance, Northern Red Sea

Straight-line distance to land

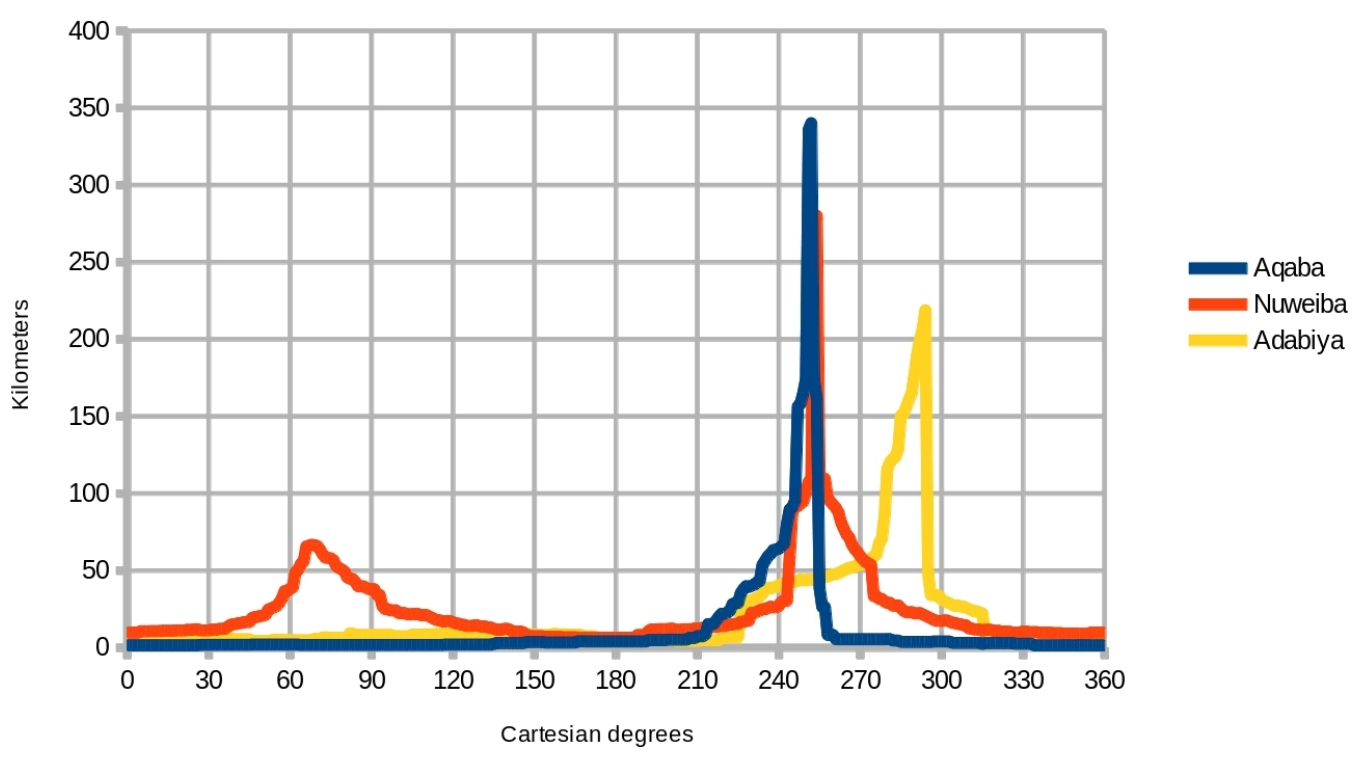

Figure 2. Fetch distance by compass direction at Aqaba; Nuweiba; and Adabiya $(10 \mathrm{~km}$ southwest of Suez). $0^{\circ}$ and $360^{\circ}=$ east; $90^{\circ}=$ north; $180^{\circ}=$ west; $270^{\circ}=$ south. The fetch is defined as the straight-line distance across water before hitting land.

The Adriatic Sea lies between Italy to the southwest and Croatia to the northeast. The UNESCO World Heritage City of Venice is situated in a lagoon at the northwestern end of the Adriatic, about $53 \mathrm{~km}$ north of the Po River delta (Figure 3). The Adriatic Sea becomes shallow toward Venice, and southeast winds cause flooding (Acqua alta in Italian) every few years. If sea level rises, more frequent high water could damage the city. What range of wind directions poses a danger to Venice? 


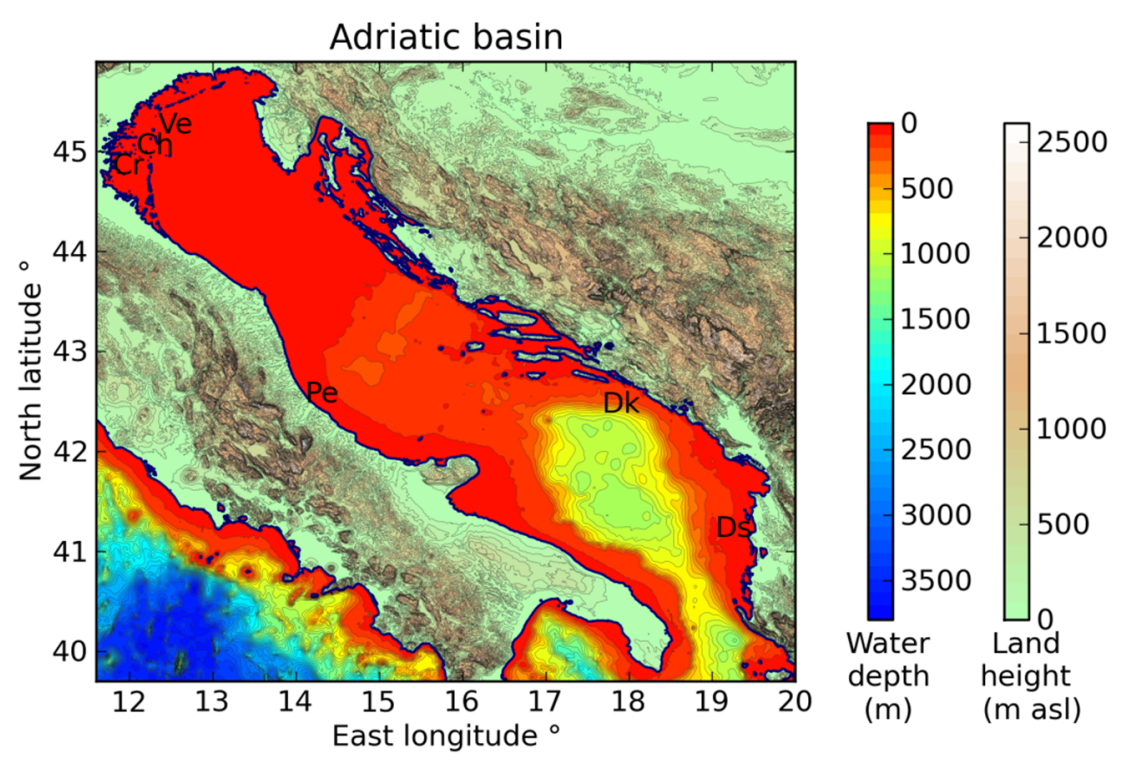

Figure 3. Adriatic Sea domain. The contour interval is $100 \mathrm{~m}$. Ve $=$ Venice; $\mathbf{C h}=$ Chioggia; $\mathbf{C r}=$ Crespino; $\mathbf{P e}=$ Pescara $\mathbf{D k}=$ Dubrovnik; Ds $=$ Durres. The SRTM30 terrain data shows the Po coastal plain as below sea level.

Figure 4 shows fetch distances along the coast of the Adriatic Sea, plotted according to compass direction. The fetch is the straight-line distance from the city across open water before hitting land, at the given angle. There are gaps in the fetch curve for Venice because small nearby islands block the fetch across the open sea.

\section{Fetch Distance, Adriatic Sea}

Straight-line distance to land

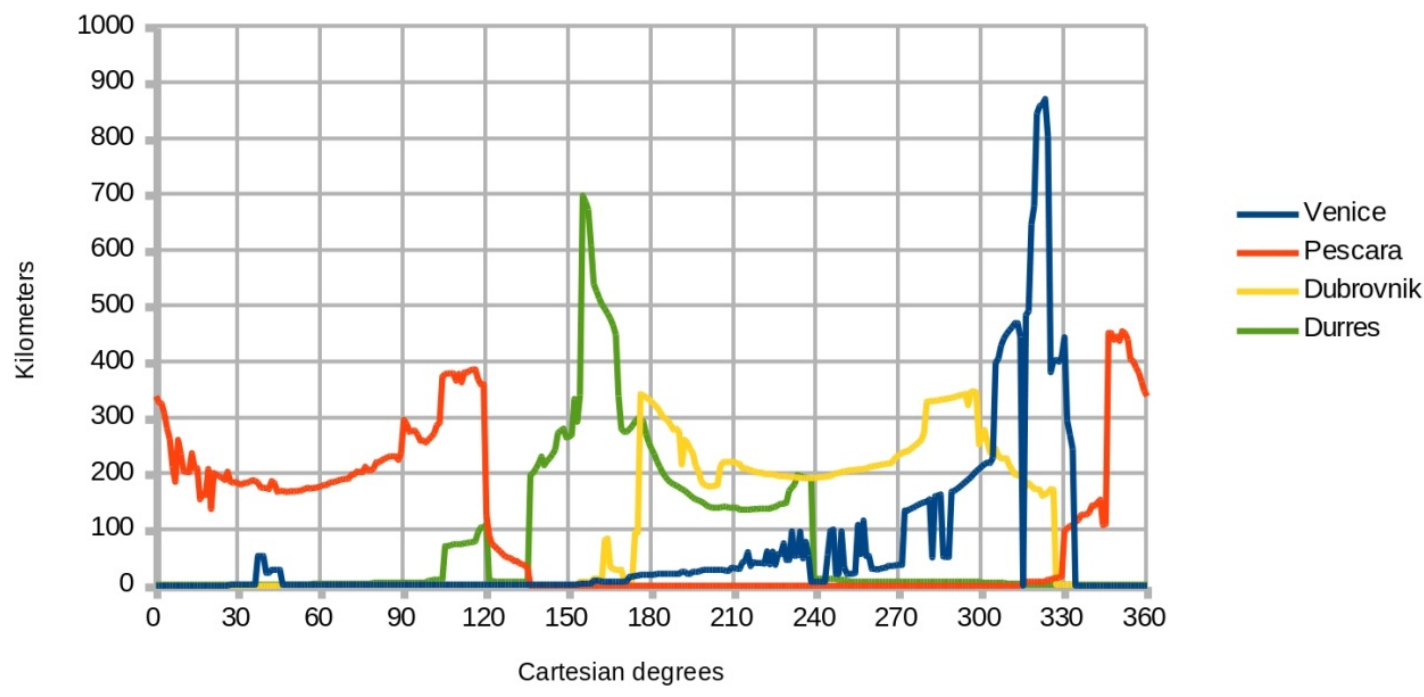

Figure 4. Fetch distance by compass direction for ports on the Adriatic Sea.

Drews and Galarneau (2015) used angle increments of $45^{\circ}$ for their directional analysis. The present study used increments of $10^{\circ}$ to achieve more accurate resolution. I applied wind stress to the model domain in a single direction, allowed the water's free surface to react to that wind stress over $24 \mathrm{~h}$, and 
measured the resulting water level at several selected points along the coast. The wind direction was then rotated and the $24 \mathrm{~h}$ repeated, throughout the full $360^{\circ}$ range of compass points. Winds blowing offshore generated wind setdown, a lowering of the water level, which is the opposite of storm surge.

\section{Results}

Figure 5 shows the water level in the northern Red Sea when winds are blowing out of the southeast (from $300^{\circ}$ Cartesian). This wind direction generates the maximum surge at Suez, since the incoming wind is aligned with the Gulf of Suez and the Red Sea proper along the longest possible fetch distance. The surge height is $1.68 \mathrm{~m}$ at Suez and $1.54 \mathrm{~m}$ at Adabiya. Table 2 shows the site names and locations for recording the simulated water level.

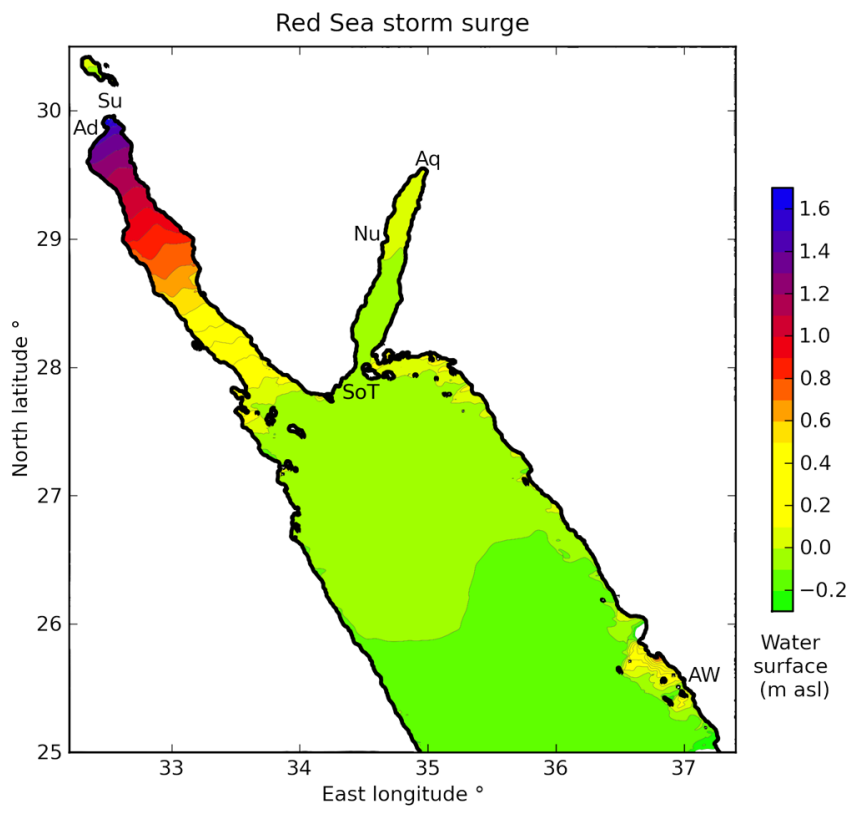

Figure 5. Red Sea surge height with wind blowing from southeast $\left(300^{\circ}\right.$ Cartesian).

Table 2. Site names and locations for the Red Sea and Adriatic Sea. Latitude and longitude are in decimal degrees north and east. The maximum simulated surge heights are in meters, and the wind directions are given in Cartesian degrees.

\begin{tabular}{cccccc}
\hline Name & Latitude & Longitude & Country & Max Surge & Direction \\
\hline Aqaba & 29.5397 & 34.9764 & Jordan & 0.055 & 230 \\
Nuweiba & 28.9838 & 34.7576 & Egypt & 0.026 & 220 \\
Tiran & 27.9858 & 34.4444 & Egypt/Saudi Arabia & 0.034 & 100 \\
Al-Wajh & 25.5467 & 36.9883 & Saudi Arabia & 1.43 & 205 \\
Adabiya & 29.8885 & 32.5486 & Egypt & 1.54 & 300 \\
Suez & 29.9449 & 32.5486 & Egypt & 1.68 & 300 \\
Venice & 45.4240 & 12.3505 & Italy & 2.02 & 320 \\
Chioggia & 45.2304 & 12.2729 & Italy & 1.94 & 330 \\
Crespino & 44.9834 & 11.9167 & Italy & 2.72 & 350 \\
Pescara & 42.4751 & 14.2251 & Italy & 0.57 & 70 \\
Dubrovnik & 42.6405 & 18.0942 & Croatia & 0.36 & 170 \\
Durres & 41.2620 & 19.4988 & Albania & 0.74 & 190 \\
\hline
\end{tabular}


Simulation experiment RS11 extends the Red Sea domain southward from $25^{\circ}$ to $20^{\circ}$ North latitude. This change increases the storm surge height to $1.77 \mathrm{~m}$ at Suez and $1.62 \mathrm{~m}$ at Adabiya. Adding $555 \mathrm{~km}$ of fetch to the Red Sea increases the storm surge at Suez by less than $10 \mathrm{~cm}$ because the Red Sea proper is very deep and does not generate much surge. The original southern boundary of $25^{\circ}$ North latitude is satisfactory for the present modeling study.

Figure 6 shows the water level when winds are from the southwest (from $230^{\circ}$ Cartesian). This direction generates the maximum possible surge at Eilat/Aqaba, since the wind is aligned with the Gulf of Aqaba. The surge height is $0.055 \mathrm{~m}$ at Aqaba, $0.025 \mathrm{~m}$ at Nuweiba, and $-0.014 \mathrm{~m}$ at the Straits of Tiran. Notice the extreme surge height $(1.3 \mathrm{~m})$ at Al-Wajh, a shallow shelf along the Saudi Arabian coast. Al-Wajh offers an exposed point on a straight shoreline to compare with the enclosed ports of Suez and Aqaba.

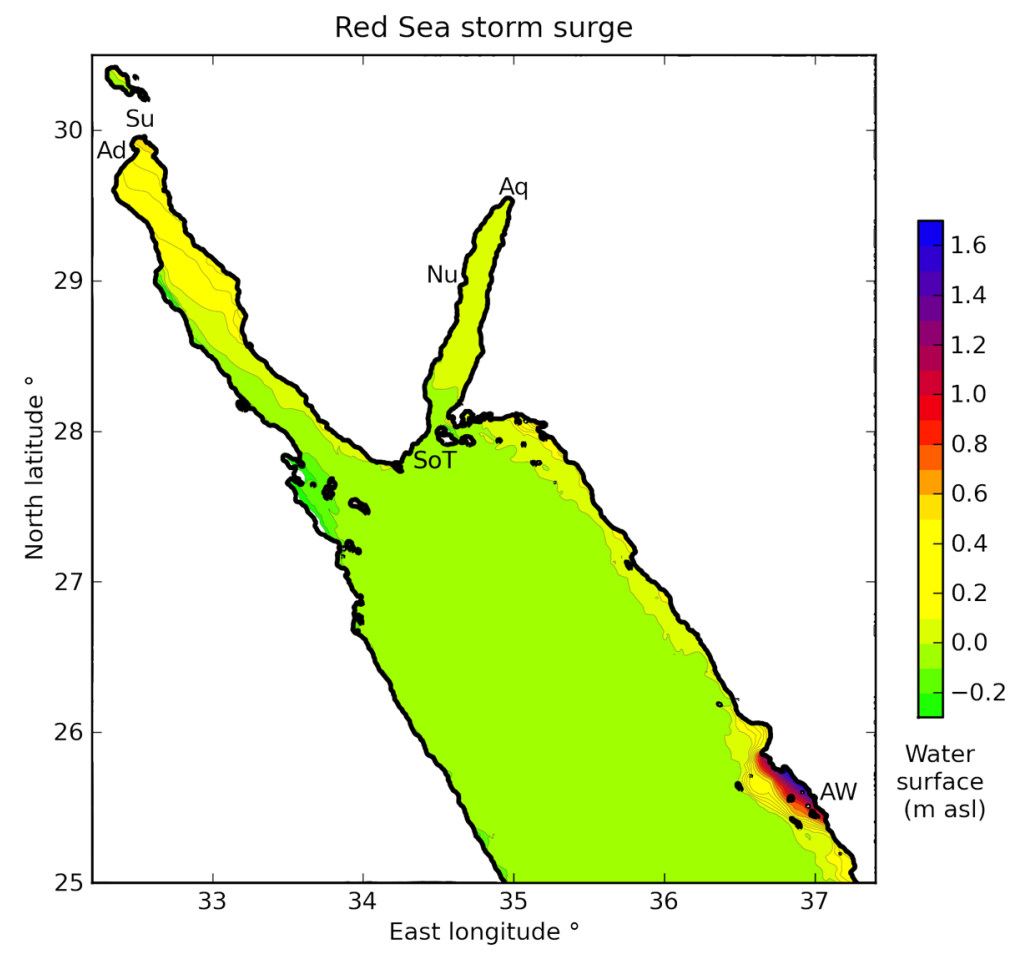

Figure 6. Red Sea surge height with wind from southwest $\left(230^{\circ}\right.$ Cartesian $)$. Note the extreme storm surge at Al-Wajh.

The directional analysis plots the surge height and wind setdown as a function of the wind angle. Figure 7 displays the results of experiment RS8 for Suez, Adabiya, and Al-Wajh. The lowest water levels reached are $1.72 \mathrm{~m}$ below sea level for Suez, $1.57 \mathrm{~m}$ below sea level for Adabiya, and $2.58 \mathrm{~m}$ below sea level for Al-Wajh. Figure 8 displays the results of RS8 for Aqaba, Nuweiba, and the Straits of Tiran; the vertical scale is different because the changes in water level are so much smaller in the Gulf of Aqaba. The lowest water levels reached are $0.050 \mathrm{~m}$ below sea level for Aqaba, $0.020 \mathrm{~m}$ below sea level for Nuweiba, and $0.032 \mathrm{~m}$ below sea level for Tiran. Table 3 lists the simulation experiments performed for the Red Sea and the Adriatic Sea. 
Water Levels in the Northern Red Sea

Directional Plot

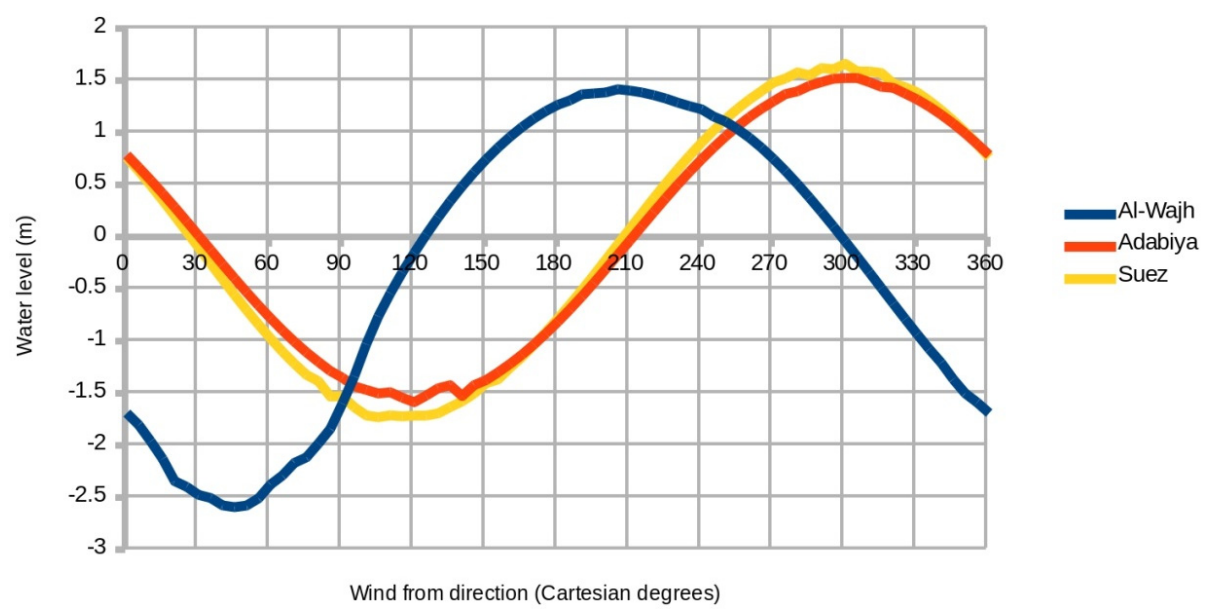

Figure 7. Directional plot for Suez, Adabiya, and Al-Wajh. Cartesian degrees are: $0^{\circ}$ and $360^{\circ}=$ east $; 90^{\circ}=$ north; $180^{\circ}=$ west $270^{\circ}=$ south .

Water Levels in the Northern Red Sea

Directional Plot

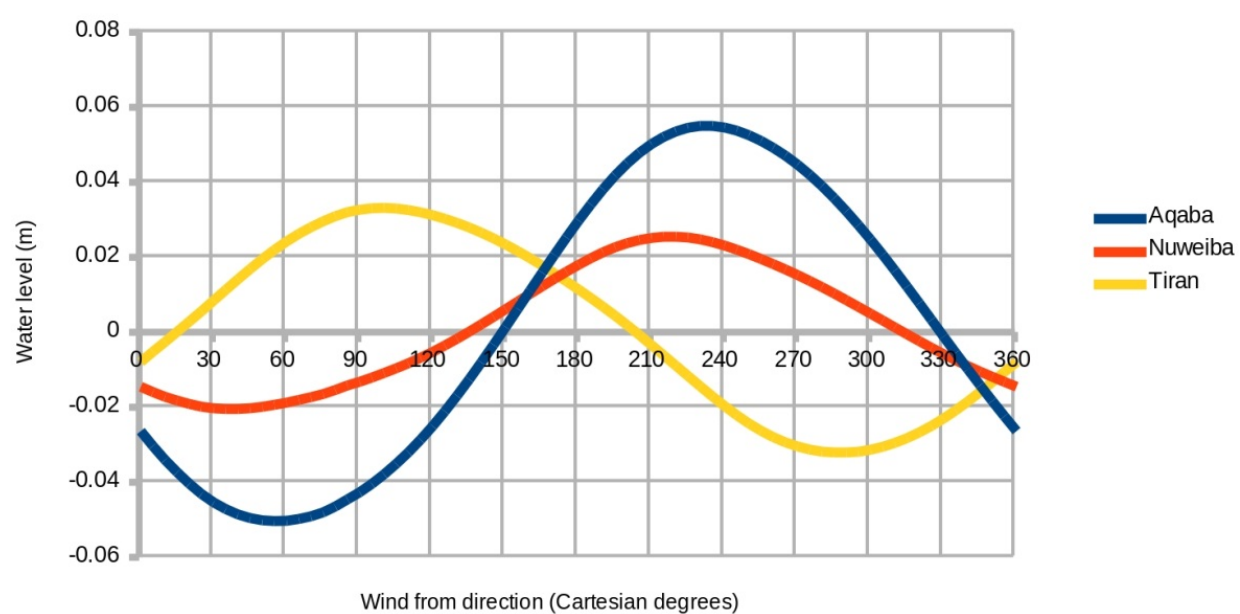

Figure 8. Directional plot for Aqaba, Nuweiba, and Tiran.

Table 3. Simulation experiments performed.

\begin{tabular}{ccc}
\hline Number & Domain & Purpose \\
\hline RS8 & Red Sea & Directional analysis \\
RS9 & Red Sea & Shallow Red Sea proper \\
RS10 & Red Sea & Shallow Gulf of Aqaba \\
RS11 & Red Sea & Domain extended southward \\
A2 & Adriatic & Directional analysis \\
\hline
\end{tabular}

The Suez Canal Authority is responsible for the safe navigation of ships that transit the canal. The extreme tidal range is $0.65 \mathrm{~m}$ in the north at Port Said, and $1.9 \mathrm{~m}$ in the south at Suez (peak-to-peak) [7]. Strong and sustained winds blowing from the southeast or northwest would approximately add to these 
tides. Using $1.7 \mathrm{~m}$ as the maximum change in water level for storm surge and wind setdown (Figure 7), the water level at Suez could drop to $2.65 \mathrm{~m}$ below mean sea level when setdown coincides with an extreme low tide. Suezmax deep-draft vessels should be made aware of such conditions. Both surge and setdown would cause unusually strong currents within the canal when they coincide with extreme tides.

Figure 9 shows water levels in the Adriatic Sea when wind blows from the southeast. Storm surge at Venice reaches its maximum height of $2.02 \mathrm{~m}$ when wind is blowing from the southeast (from $320^{\circ}$ Cartesian). The maximum wind setdown of $2.28 \mathrm{~m}$ below sea occurs at Venice when wind is blowing from the northwest (from $140^{\circ}$ Cartesian). Wind setdown is slightly greater in magnitude than storm surge because shallow waters are more affected by wind stress.

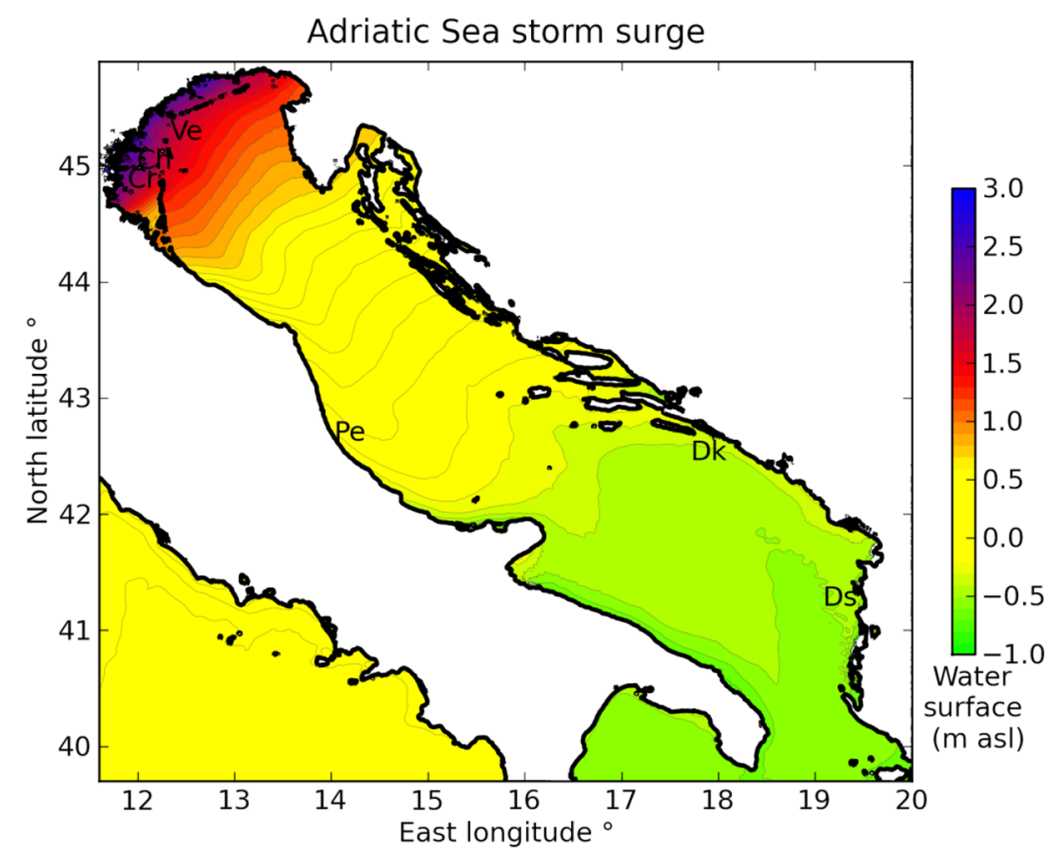

Figure 9. Adriatic surge height with wind from southeast $\left(320^{\circ}\right.$ Cartesian $)$.

The highest water level recorded in Venice occurred on November 4, 1966; the Adriatic Sea rose to $1.94 \mathrm{~m}$ above mean sea level [8]. The maximum surge height of $2.02 \mathrm{~m}$ calculated by the directional analysis exceeded this observed maximum by $4 \%$, demonstrating that these model results are realistic simulations of extreme surge events at Venice.

Figures 10 and 11 display the results of experiment A2 for ports on the Adriatic Sea; Figure 10 shows the directional analysis for Venice, Chioggia, and Crespino. Crespino is a village on the Po River $52 \mathrm{~km}$ inland from the river's mouth. The ocean model and SRTM30 data calculate extensive inland flooding of the Po coastal plain when wind blows from the southeast. The curve for Crespino is flattened on the bottom because water takes longer to drain out the Po river channel than to drain from the Venetian lagoon.

The maximum surge at Venice, and therefore the maximum vulnerability of the city to flooding, occurs when the wind blows from the southeast at $320^{\circ}$ Cartesian. Surge height remains over $90 \%$ of the peak value for wind directions between $300^{\circ}$ and $340^{\circ}$, or within $\pm 20^{\circ}$ of the "optimum" wind direction (Figure 10). Venice is vulnerable to storm surge driven by winds blowing from directions substantially different than the theoretical optimum of $320^{\circ}$. 
Water Levels in the Adriatic Sea

Directional Plot

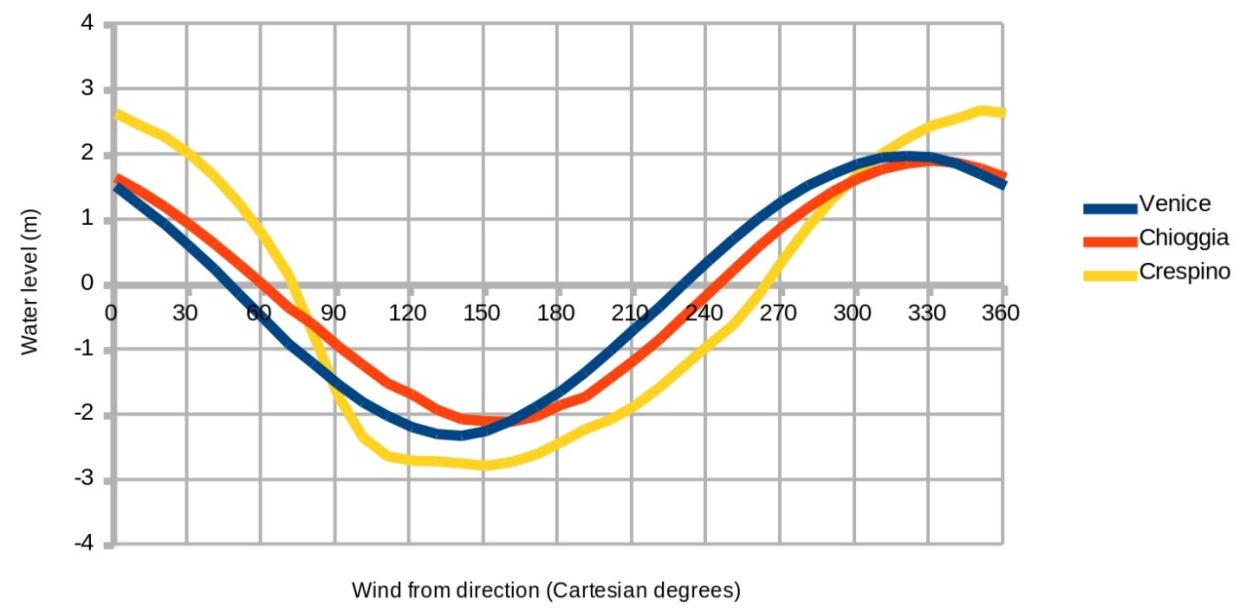

Figure 10. Directional plot for Venice, Chioggia, and Crespino.

Figure 11 shows the results of the directional analysis for Pescara (Italy), Dubrovnik (Croatia), and Durres (Albania). Pescara was chosen as an exposed port city along a straight coastline; it serves as a comparison for the sheltered location of Venice. Water levels range from -0.58 to $0.57 \mathrm{~m}$ at Pescara, from -0.37 to $0.36 \mathrm{~m}$ at Dubrovnik, and from -0.78 to $0.74 \mathrm{~m}$ at Durres.

Water Levels in the Adriatic Sea

Directional Plot

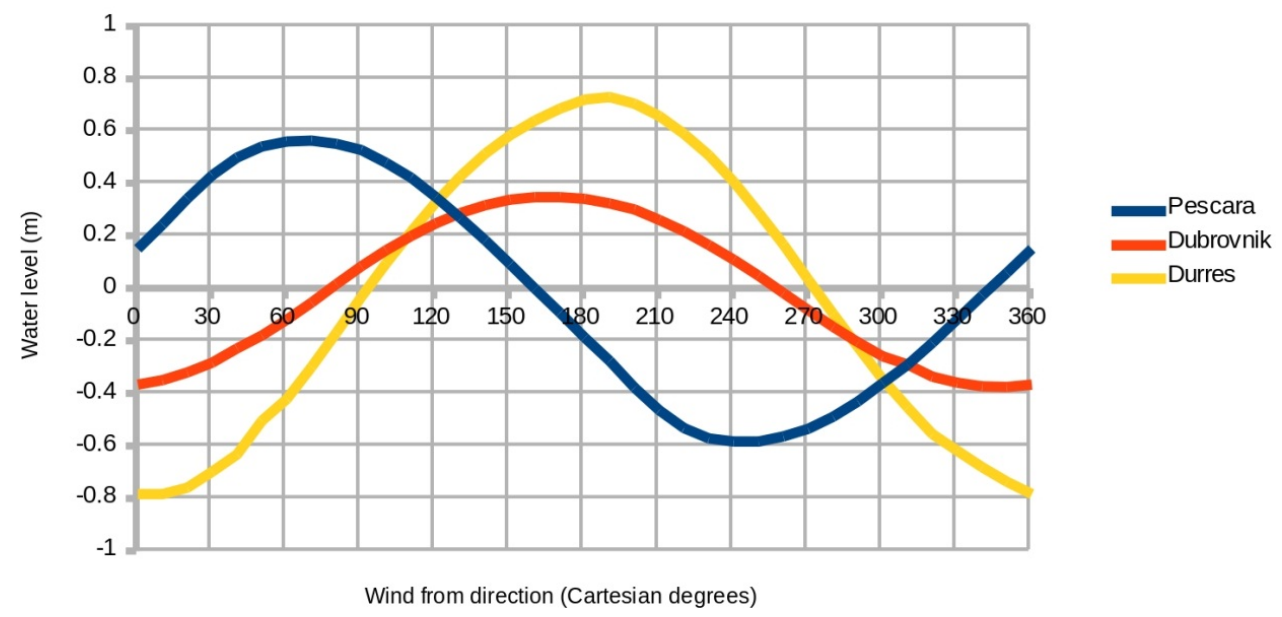

Figure 11. Directional plot for Pescara, Dubrovnik, and Durres.

Plots of the directional analysis reveal an interesting result: There is no significant narrowing of the peak for port cities at the end of a long inlet. The plotted curves of water level as a function of wind angle are all sinusoidal. There is no qualitative difference between protected coastal sites and the exposed sites. Storm surge at Suez is affected by wind direction in the same way as storm surge at Pescara.

Why are surge heights so much smaller for the Gulf of Aqaba than for the Gulf of Suez? Part of the reason is that the Red Sea proper is aligned with the Gulf of Suez, and therefore water levels in the Red Sea tend to enhance the surge at Suez and diminish the surge at Aqaba. But the dominant reason is that 
the bathymetry of Aqaba is too deep to generate significant storm surge or wind setdown. Experiment RS10 tests this hypothesis by reducing the depth of the Gulf of Aqaba by 95\%, making it comparable to the Gulf of Suez. The average depth becomes $48 \mathrm{~m}$. When the bathymetry northeast of Tiran is modified in this manner, the water levels vary from $-0.73 \mathrm{~m}$ to $0.73 \mathrm{~m}$ at Aqaba, from -0.42 to 0.42 at Nuweiba, and from -0.025 to 0.031 at the Straits of Tiran. Shallow water surges more. Figure 12 shows the values of surge height and wind setdown that result from a range of shallow depths for the Gulf of Aqaba. Wind setdown is comparable in magnitude to storm surge.

Storm Surge and Wind Setdown at Aqaba

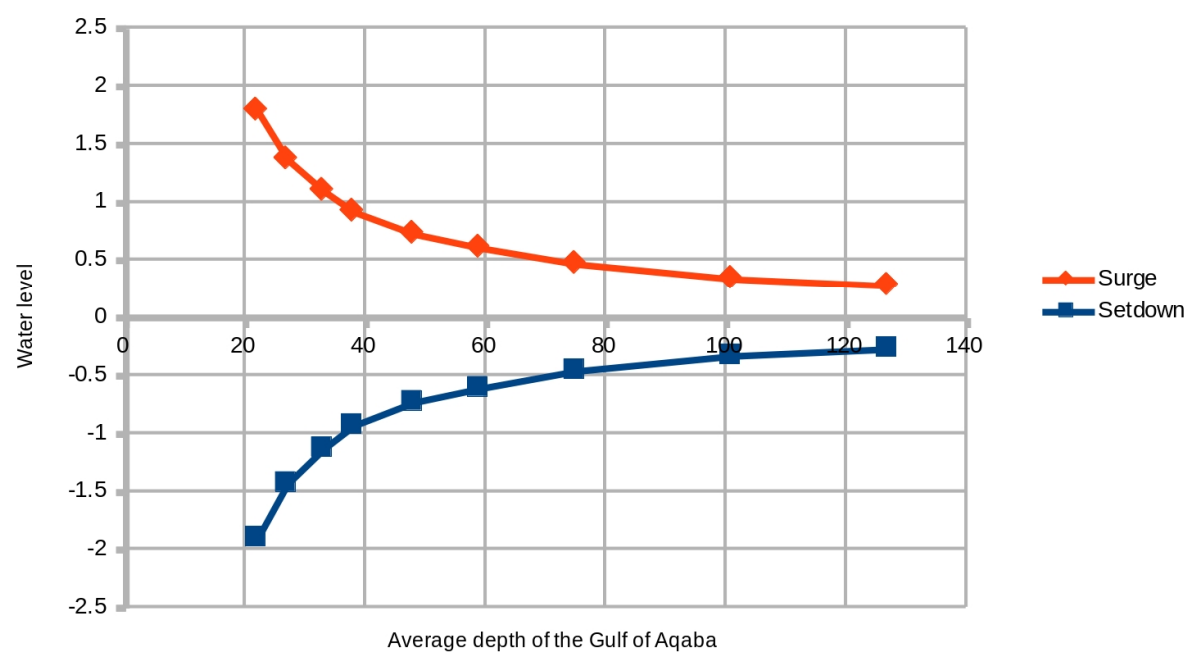

Figure 12. Storm surge and wind setdown at Aqaba when the Gulf of Aqaba is made shallow.

To further illustrate the effect of water depth on storm surge, experiment RS9 reduced the depth of the Red Sea proper (south of Sinai) and measured the resulting water levels at Adabiya for wind angles of $120^{\circ}$ and $300^{\circ}$ (Cartesian). Storm surge at Adabiya rose to $1.95 \mathrm{~m}$ above sea level, and wind setdown dropped to $2.01 \mathrm{~m}$ below sea level. Thus the water displacement for a shallow Red Sea proper increased by $27 \%$ and $28 \%$, respectively.

\section{Materials and Methods}

COAWST is configured to run in its two-dimensional mode, without coupling to WRF or SWAN. The air-to-sea drag coefficient is described by Oey et al. [9] To compensate for 2-D mode and the lack of waves, the calculated wind stress is multiplied by the same factor of 1.63 used in previous studies for Lake Erie [5] and the Atlantic coast of the United States [6]. The quadratic bottom drag coefficient (RDRG2) for ROMS is $1.0 \times 10^{-3}$. The ocean model does not include tides. The critical depth for wetting and drying is $0.5 \mathrm{~m}$, and the time step is $2.0 \mathrm{~s}$. Any open domain boundaries that are not land surface are no-slip walls.

The Shuttle Radar Topography Mission supplied bathymetry and topography at a grid resolution of 30 arc-seconds (SRTM30) [10]. Grid cells for the Red Sea domain are about $900 \mathrm{~m}$ wide, and $800 \mathrm{~m}$ wide for the Adriatic Sea.

The wind speed ramps up from 0 to $28 \mathrm{~m} / \mathrm{s}$ over a period of $24 \mathrm{~h}$. This ramp-up time is necessary to avoid seiche oscillations within the enclosed seas. $28 \mathrm{~m} / \mathrm{s}$ approximates a medium-strength tropical storm 
on the Saffir-Simpson scale of hurricane winds. Sea level measurements are recorded at the end of $24 \mathrm{~h}$. The wind field for each test case is uniform in speed and direction across the entire domain. The wind direction rotates around the compass in increments of $10^{\circ}$, producing 36 test cases for each full experiment in the directional analysis.

Table 3 lists all the model experiments. The Gulf of Aqaba and the Red Sea proper were reduced in depth for experiments RS10 and RS9, respectively. Bathymetry deeper than the $25 \mathrm{~m}$ isobath was reduced by $95 \%$ according to the following transformation:

$$
\text { newDepth }=((\text { originalDepth }-25.0) \times 0.05)+25.0
$$

Underwater values in Equation (1) are positive. This transformation makes the Gulf of Aqaba and the Red Sea proper comparable in depth to the Gulf of Suez, while retaining some of the bottom roughness. Experiment RS10 replaces the fraction 0.05 in Equation (1) with a range of values from 0.00 to 0.20 (see Figure 12).

\section{Discussion and Conclusions}

The directional analysis proposed by Drews and Galarneau [6] has been implemented here in angle increments of $10^{\circ}$ in order to determine the potential of a coastal city for storm surge with respect to wind direction. For the cases studied here, the maximum and minimum water levels were generated by angles differing by $180^{\circ}$, and the response across all compass directions closely approximated a sinusoidal curve. Ports at the end of a long narrow inlet exhibit this response because the wind stress on the inlet acts in proportion to the cosine between the wind direction and the long axis of the inlet.

Storm surge maps are commonly created by simulating a series of hurricane tracks making landfall, then combining the maximum surge heights into a single map [6]. The directional analysis provides another way of looking at the risk posed by tropical cyclones and other windstorms. The directional plot reveals at a glance what is the most dangerous wind direction for storm surge, and the opposite angle that will interfere with ship navigation when water levels drop.

This paper examined the influence on storm surge of ocean depth, fetch distance, and wind direction. (The wind speed was left uniform across all experiments.) Shallow waters are more susceptible to storm surge than deep ocean basins. In general, a longer fetch will produce higher storm surge, but the exact relationship is complex and dependent on the local geography. Changes in wind direction produced a simple curve resembling the cosine function for the cases studied here.

\section{Acknowledgments}

The National Center for Atmospheric Research provided computational support. NCAR is sponsored by the National Science Foundation. Any opinions, findings and conclusions or recommendations expressed in the publication are those of the author and do not necessarily reflect the views of the National Science Foundation. I thank Yu-heng Tseng and Thomas Galarneau for their manuscript review and comments.

\section{Author Contributions}

Carl Drews conducted the research and wrote the paper. 


\section{Conflicts of Interest}

The author has written and published a book titled "Between Migdol and the Sea" (Carl Drews, 2014) about the Hebrew Exodus from Egypt.

\section{References}

1. Knabb, R.; Rhome, J.; Brown, D. Tropical Cyclone Report Hurricane Katrina 23-30 August 2005. Available online: http://www.disastersrus.org/katrina/TCR-AL122005_Katrina.pdf (accessed on 27 March 2014).

2. Teves, O.; Bodeen, C. Typhoon Haiyan Storm Surges Caught Philippines by Surprise. Available online: http://www.weather.com/news/weather-hurricanes/typhoon-haiyan-storm-surges20131111 (accessed on 11 November 2013).

3. Warner, J.C.; Armstrong, B.; He, R.; Zambon, J.B. Development of a coupled ocean-atmospherewave-sediment transport (coawst) modeling system. Ocean Model. 2010, 35, 230-244.

4. Drews, C.; Han, W. Dynamics of wind setdown at Suez and the Eastern Nile Delta. PLoS ONE 2010, 5, e12481.

5. Drews, C. Using wind setdown and storm surge on lake erie to calibrate the air-sea drag coefficient. PLOS ONE 2013, 8, e72510.

6. Drews, C.; Galarneau, T.J.J. Directional analysis of the storm surge from hurricane sandy 2012, with applications to charleston, new orleans, and the philippines. PLOS ONE 2015, 10, e0122113.

7. Authority, S.C. About Suez Canal. Available online: http://www.suezcanal.gov.eg/sc.aspx?show=17 (accessed on 27 March 2015).

8. di Venezia, C. 4 Novembre 1966. Available online: http://www.comune.venezia.it/flex/cm/pages/ ServeBLOB.php/L/IT/IDPagina/2053 (accessed on 25 March 2015).

9. Oey, L.Y.; Ezer, T.; Wang, D.P.; Fan, S.J.; Yin, X.Q. Loop current warming by hurricane wilma. Geophys. Res. Lett. 2006, 33, L08613, doi:10.1029/2006GL025873.

10. Survey, U.S.G. Shuttle Radar Topography Mission. Available online: http://dds.cr.usgs.gov/ srtm/version2_1/ (accessed on 28 July 2014).

(C) 2015 by the authors; licensee MDPI, Basel, Switzerland. This article is an open access article distributed under the terms and conditions of the Creative Commons Attribution license (http://creativecommons.org/licenses/by/4.0/). 